THEORIA ET HISTORIA SCIENTIARUM, VOL. XII

Ed. Nicolaus Copernicus University 2015

DOI: http://dx.doi.org/10.12775/ths.2015.007

loana Zirra

Faculty of Foreign Literatures and Letters, The English Department, University of Bucharest

ioana.zirra@gmail.com

\title{
James Joyce's Ironical Memory: Jungian versus Parallactic Literary (Re-)Cognition in the Cultural-Gift Novel Titled Ulysses
}

\begin{abstract}
Approaching James Joyce's Ulysses from the point of view of the cognitive field of cultural memory studies involves an account about the difficulties encountered on the way, followed by the discovery of limitations that the ironies of the Joycean fictional experiment introduce in the standard handling of four cultural memory modes (experiential, mythicizing, antagonistic and reflexive, according to Astrid Erll's 2008 study "Literature, Film and the Mediality of Cultural Memory"). The complexities of the modernist cultural intra-mediation memory modes are explained by reference to self-reflexive postcreation, fabrication, parallelism and parallax; the latter complicates parallelism, just as postcreation, a self-reflexive term coined by Stephen Dedalus in the Ulyssean episode "Oxen of the Sun" complicates fabrication; with help from The Parallactic View by Slavoj Žižek, the species of Joycean irony are explained so as to refute Carl Gustav Jung's dismissal of Ulysses as meaningless in 1932 .
\end{abstract}

Keywords: cultural memory; self-reflexive (intra-)mediation; stable and unstable irony; fabrication; parallelism; postcreation; parallax.

Through its ambitiously modernist project and two dandy male protagonists, James Joyce's novel Ulysses stands out owing to its way of drawing on a number of cognitive peaks - some handed down via centuries of literary rhetoric and canonic religiosity, others quite recent, new-fangled ones, 
plucked from the bosom of methodical science. Hence the attempt to join the hermeneutic circle of insights occasioned for each generation of scholars equipped with the latest cognition tools. The first part of the paper is an account about the attempt of enlarging the horizon of Ulyssean expectations by applying to Joyce's literary monument of 1922, this annus mirabilis of English modernism, the theoretical apparatus of cultural memory studies, research field established in the first decade of our new millennium. On the way, the first challenge encountered was the task of answering, from the cultural memory studies point of view, Carl Gustav Jung's accusation that Ulysses was a meaningless book; this involved finding arguments against its incapacity of being a portable monument. Could Ann Rigney's statement that 'texts are 'portable' monuments, which can be carried over into new situations" (Rigney 2004: 383 ) be used to answer convincingly in the negative the questions raised by the Jungian complaints?

In 1932, Jung declared that the book "can just as well be read backwards, for it has no back, no front, no top and no bottom" (Jung 2003:130), as "it begins in the void and ends in the void" (Jung 2003: 128). This might well mean that the Joycean monument to the Homeric past failed to be "portable," or make contact with the present locations where it was transported, because Jung also wrote:

The Ulysses of my title has to do with James Joyce and not with that shrewd and storm-driven figure of Homer's world who knew how to escape by guile and wily deeds the enmity and vengeance of gods and men [...]. Joyce's Ulysses, very much unlike his ancient namesake, is a passive, merely perceiving consciousness, a mere eye, ear, nose, and mouth, a sensory nerve. (Jung 2003: 127-28)

No wonder, then, that the article was titled "Ulysses a Monologue," since it denied Joyce's experiment the power of communicating in the exterior. With more competence as a literary connoisseur, Jung might have recognized, at least, that Joyce worked in the line of the new dramatic method of narration that the French called monologue intérieur. As things stand, in denying the power of the later writer to measure up with (or to commemorate) the Homeric prototype, Jung can be seen to have dismissed the rich Joycean cultural (inter)text as a gift over which there still hovered a paremiological shadow tainting many a Greek gift, timeo Danaos et dona ferentes.

Jung's blindness to the merits of the modernist Ulysses went as far as to declare it as simply soporific. After showing that "the incredible versatility of Joyce's style has a monotonous and hypnotic effect," Jung illustrates this 
by a concrete occurrence: "Arrived at page 135 [of Ulysses], after making several heroic efforts to get at the book, to 'do it justice', as the phrase goes, I fell at last into profound slumber" (and there follows a detailed note about the part of Joyce's text that triggered his Jungian slumber) (Jung 2003: 129-130).

This was too much to bear and I embarked upon the defence of the novelwhich Joyce himself actually regarded as an epic, "the epic of two races, Israel and Ireland" (Joyce 1975: 273). How did the Joycean epic, then, work as a portable monument to mediate the credible cont(r)act of the present with the past? Interrogating the text, I discovered a figure which could function as part of the mandala giving one access to the book's development on the path of individuation: the parallax.

The episode "Lestrygonians," with the first two occurrences of the word signalling the failure of individual minds to coincide doubled by hopes for bridging the gap after recognizing it, might be regarded as a blueprint for the final moment of grace describable as parallactic, in "Ithaca." In this interpretation, the homecoming at the end of the novel gives definite shape to a number of mere intuitions about distances that, in fact, keep people together reflexively; the parallax sensor points to the successful mediation of human experience with the mind. The way Mr Bloom's more reflective mind processes the difference between Molly's mental disorientation and his own orientation can be read in the following quotation:

Mr Bloom moved forward, raising his troubled eyes. Think no more about that. After one. Timeball on the ballastoffice is down. Dunsink time. Fascinating little book that is of Lord Robert Ball's. Parallax. I never exactly understood. There's a priest. Could ask him. Par it's Greek: parallel, parallax. Met him pike hoses she called it till I told her about the transmigration. (Joyce 1986:126).

Because he has a Ulyssean inventive, and always (subliminally) empathetic, mind, $\mathrm{Mr}$ Bloom associates his own first-hand ignorance regarding the more precise meaning of parallax, in the last sentence, with Molly Bloom's ("she," her) approximation of the word metempsychosis, "[m]et him pike hoses," in the earlier scene in the novel, in "Calypso," where the husband had found a way to explain metempsychosis very simply to his wife, when saying that the Greeks "used to believe you could be changed into an animal or a tree, for instance" (Joyce 1986: 53, 56). He had given nymphs as a palpable example of what the Greeks invented, because there was the photo of one over the Blooms' marital bed. There is hope for 
cognition in Mr Bloom's patient mind, which recalls and redraws former thoughts to arrive at profitable explanations.

The success in measuring and formulating the distance between minds in parallactic terms is greatest in the scene which takes place under the stars in "Ithaca." Here, Mr Bloom provides a full explanation of the term:

Parallax, or the parallactic drift of so called fixed stars, in reality evermoving wanderers from immeasurably remote eons to infinitely remote futures in comparison with which the years, threescore and ten, of alloted human life formed a parenthesis of infinitesimal brevity. (Joyce 1986: 573)

Because both the story-line and the characters' consciousness are brought together under the stars, the figure of the parallax encrypts the moment of plenitude which is known as the main protagonists' privileged encounter as father and son under the longlasting stars, outside Mr Bloom's house at 7 Eccles Street, in Dublin. Mr Bloom defines the parallax for Stephen in precise astronomical and geometrical terms - but the figure itself can be used to describe the progress of the whole book, away from what Jung noticed (and dismissed) as being the unchecked proliferation of the (passive) characters' thoughts moving in the void.

The demonstration about how this figure migrates from one character's mind to the mind of another takes more than the invocation of a dialogical scene, albeit one in which consciousnesses communicate and expand towards immensity by evoking "immeasurably remote eons" and "infinitely remote futures" as the background - or, indeed, the foreground - to "the infinitesimal brevity" of human life. The first stage in the demonstration assembles the analyses of cultural memory species (viz. "modes of mediation": the experiential, mythicizing, antagonistic and reflective ones in Astrid Erll's 2008 systematic presentation of "Literature, Film, and the Mediality of Cultural Memory") for showing how the Joycean cultural memory is ironical. It can be considered that Joyce adds an extra mode, as a surprising literary gift, in Ulysses: ironical cultural memory. The point of my title's first words will appear more clearly when placing side by side the compositional rhetoric of the literary text and the rhetoric of cultural memory mediation, more precisely Erll's discussion of intra-mediation. The next stage of the paper will connect into a formulaic description of the novel the collocation of the words "parallax" and "parallel" in the previously quoted passage containing Mr Bloom's stream of consciousness. As will be seen, the vehicle that ironically mediates between mere parallelism and parallax is fabrication, because fabrication is foregrounded and explained 
together with the parallax in the same last part of Ulysses, the Homecoming or Nostos, in the episode "Eumaeus." The self-reflexive terms explanatory for the ironical designs of the Ulyssean implied author work in pairs: parallax/ parallel, postcreation/ fabrication - with the privileged first terms in the two pairs only coming to the fore after the readers have been taunted long enough, being forced to engage with the weaker members of the pairs. Hence, the stunted parallelisms with the Homeric prototype that tortured Jung and the declarations of even more reliable Joyce critics that "Eumaeus" is one of the boring, least spectacular episodes of Ulysses. Slavoj Žižek's 2006 title, The Parallax View, is finally brought to bear upon the paper's argument because it is only by (re)cognizing the subtleties of the Trojan Horse as a cultural gift that its ruse will prevent the walls of (literary) cognition from collapsing.

A few clarifications are in order before recognizing the complexities of the Joycean rhetoric when understood as intra-mediation. According to Astrid Erll, intra-mediation is responsible for the figural constitution of collective memory discourses as opposed, on the one hand, to intermediation, which acts on the temporal axis (as re-mediation or premediation of the past in the present), and, on the other hand, to pluri-medial translation of memory from one cultural context and form of communication to another (Erll 2008: 390, 391). According to Erll, there are four standard intra-mediation modes: the experiential one, which still bears the mark of individual sensibility and cognition patterns, the mythicizing, which recycles the protocols of the tribe, the antagonistic ideologically polarized mode, and, finally, the reflexive. The latter discourse form mediates cultural memory self-reflexively, too, with its second order observation of memory processes. In Ulysses, James Joyce's experiment merges all of these modes because of the way his characters' minds are dramatized and articulated. The amazing vistas opened on the everyday world by Mr Bloom and Stephen, with their consciousness revealing its fundamental processes for hundreds of pages, forces the reader to shift ground between experiential points of view constantly. The starting point for Stephen's stream of consciousness, in the episode "Telemachus," is the word "Chrysostomos" - ironically applied to the first blasphemer pictured in the novel, Buck Mulligan and to his gold tooth showing while he speaks as irreverently as can be about things, all things. The word "Chrysostomos" bears the mark of Stephen Dedalus's dandyism rooted in a knowledge of the cultural, religious past and is very different both from Buck Mulligan's highly metropolitan conversation about Wilde, Swinburne, Shakespeare and Oxford and from Mr Bloom's dandyism. The dandy's concentration (on the self) strives 
to escape the tyranny of custom/conventions in everyday encounters by all means. Forced to come back from Paris by his mother's death, the dandy Stephen takes refuge in his knowledge of the scholastic past. The inwardness of Mr Bloom's mind is marked by his Jewish cultural memories and wanders from the immediate Western experience to the fascinating Orient. These two dandies also typically take refuge from the exterior declaring themselves dead to the world by going about dressed in black (they are the only two characters in the book noted for wearing black, gone in mourning). Stephen is still in mourning after the death of his mother, apparently having nobody to commune with, since his best friend Mulligan has grievously offended him through irresponsible chatter and blatant lack of compassion; he would even deny Stephen the right to mourn (or be melancholy) - or "brood upon love's bitter mystery," as he puts it, following a cue from Yeats's poem "Who Goes With Fergus?" Similarly, Mr Bloom has to cope with unbearable death and love experiences: since the death of his only son, Ruddy, the marital love relationship with his wife has been seriously troubled and she has become amorously involved with another man, the boss of her operatic, social life, Blazes Boylan. The experientially encoded cultural memories invoked by Stephen in order to screen himself from the hurtful surrounding world reach, on the vertical or transcendent line of cultural memory, towards religion and literature, with Aquinas, Shakespeare, Lessing, finally bearing upon Yeats, AE (George William Russell) and other intellectuals of the day to be met with in Dublin (as can be seen in the episode set in the National Irish Library, in "Scylla and Charibdis"). On the other hand, Mr Bloom recycles the cultural memory patterns of the Oriental (t)races, the mythical Hebrews and the modern Jews who were at the time reclaiming a land of their own in Palestine. By contrast to Stephen's, Mr Bloom's interest is in the positive sciences and contributes several parallax passages ${ }^{1}$. His inventive mind flourishes in the practical domain, always ready to create useful or amusing links that entertain the reader. He has a knack for popularizing or explaining all things and make them accessible even to the most ordinary minds such as his wife's. But whereas Mr Bloom's explanations come from first-hand experience and are tentative before reaching the essential, Stephen's come directly in an essentialized and very bookish cultural memory discourse as proved by various commentators of the Ulysses text, from Gifford and Seidman's separate edition of (interpretive) Notes for James Joyce's Ulysses to the (documentary, factual) notes by Sam Slote included in the 2012 edition

1 After "Lestrygonians," the word recurs as an obsessive figure of Mr Bloom's mind in "Oxen of the Sun" and "Circe" (Joyce 1986: 338, 398, 418). 
of the book. Experientially, then, the cultural memory charted in the novel is complementary before being exceptionally exhaustive; it is invested in the two complementary prodigious characters' minds. Working on the vertical, Stephen Dedalus's rich memories connect Western philosophical and religious transcendence, but his relationships on the horizontal, everyday experience axis remain frustrating. As an expert in everyday life matters, Mr Bloom finds endlessly ingenious ways of keeping frustrations at bay. Readers are, consequently prepared experientially, not just suddenly invited, to accept the father-and-son relationship connecting the complementary protagonists of the book. As regards the antagonistic cultural memory mode, it is presented at length (and satirized with its mythical self-inflations) in the "Cyclops" episode in connection to Mr Bloom's encounter with the lowbrow, narrow minded nationalists grouped around the Citizen. But so had also been treated, because reflexively dismissed, Buck Mulligan's and Mr Deasy's Anglo-Irish antagonistic mode of mediating the past in its more upper-class version. Finally, reflexivity, tolerance is what unites the novel's older and younger protagonists who put side by side the common mythical roots of Christianity and Hebraism to defeat antagonist versions of history and myth

The ways of cultural memory which fashions the characters' reflexive complementariness reach the reader, however, via constantly shifting, dialogic discourse, where both heteroglossia and polyglossia are at their height, by Bakhtinian standards. We are plunged in the thick of modernist irony by Joyce's criss-crossing monologues, dialogues in which one character is silently opposing his stream of consciousness to the talking heads of our everyday world. It becomes the task of the patient reader to seek for the roots of stable dramatic irony behind the infinitely ironic instabilities of the text.

In keeping with Wayne Booth's explanations in A Rhetoric of Irony (see especially chapters 5 and 8), unstable or infinite irony "does not allow the reader to stand securely on the author's pedestal" (Booth 1974: 256) and courts non-meaning, meaninglessness (which evokes the Jungian complaint against Joyce's Ulysses). Because infinite (inexhaustibly productive) irony depends on suspending cognition between characters' and implied authors' points of view, it does not actually fit Joyce's text. For one thing, because the characters are experientially strong and resist cultural stereotypes. In addition, the wanderings of the protagonists allow for a momentary and momentous homecoming, in the third part of Ulysses. Thirdly, it is not in virtue of the overt cultural memory parallelisms (intertextualities) with the Odyssey, or with Hamlet, that the text is ironical, only. The merger of the experiential, reflective, antagonistic and reflexive cultural memory 
modes makes the parallelism with the classics be enacted always with a difference, by the implied author of Ulysses. He superimposes displaced myth upon the disenchanted world, hinting, in this way, with antagonisms, to pertinent differences of the present in respect to the past.

The implicit irony can be glimpsed from the titles of episodes that already indicate the mythical joined to the antagonistic (and intriguing) uses of cultural memory. The old man of the sea, Proteus, for example, is in Joyce's text a self-communing young man (Stephen) walking on Sandymount beach, though capable of attracting, like a lightning rod, all the sky's effervescence. Calypso is a Penelope also and she keeps in thralldom the husband in their own home, forcing him, by her sensual existence, to become the wandering Jew and a modern dysphorically roaming Odysseus. The ultimate irony of the text is to be found in the fact that, through the unpunctuated monologue of Molly Bloom, modern femininity is cast as that of a Penelope who is more akin to Messalina, though a Messalina. The criminality of modern women is, however, abated, it is reduced to zero, actually, owing to the profound way in which her thoughts can be contained by the male conscience of the husband transcribing, in a sympathetic, friendly, and extremely entertaining way, her most intimate thoughts.

In fact, it has now become possible to prove that the parallel with the literary classics is not only ironical in being parallactic (rather than simply parallel).

If, as shown before, the cultural intertext with the Odyssey, for example, is a stimulus for reflexive memory intra-mediation, i.e. for discovering the rhetoric of "critical reflection upon the processes of representation" and cultural memory-work (Erll 2008: 391), intra-textuality is another important means of literary, cultural mediation. When correlating the intra-textual cross-references to parallax as alterations of simple analogical memory processes with the other innovatively used Joycean word: "postcreation," the self-referentiality of the literary text will come to the fore.

The moment when, in "Oxen of the Sun," Stephen advances his theory of the postcreation becomes a turning point: it marks the passage from monological reflexivity to genuinely cultural, public communication in the history of Stephen's meditative, loner's self.

His words were then these as followeth: Know all men, he said [posing as Christ at the Last Supper seated at the head of the table], time's ruins build eternity's mansions. What means this? Desire's wind blasts the thorntree but after it becomes from a bramblebush to be a rose upon the rood of time. Mark me now. In woman's womb 
word is made flesh but in the spirit of the maker all flesh that passes becomes the word that shall not pass away. This is the postcreation.

Omnis caro ad te veniet. (Joyce 1986:320)

After this pronouncement sealed by the Latin words of the Requiem and introduced by the hidden allusion to the Yeatsian poem "To the Rose upon the Rood [arch. cross] of Time, " Stephen becomes radically transformed. He is no longer the artist without an oeuvre, the target of Mulligan's repeated irony, but a fully fledged skilful creator who has it in his power to imitate with considerable ease, and recognizably, the most reputed English literary styles. The parodies of the canonical English prose-styles in chronological sequence from Sir Thomas Mallory to Dickens, Carlyle, Ruskin and Pater can only be understood as being applications of Stephen's own English trained cognition and wit to the Dublin and Bloomsday narrative about the herd of young male defilers of procreation in the lobby of the Holles Street Maternity hospital. The maternity is cast as a temple by the formulaic introductory incantations of the "Oxen of the Sun" episode: "Deshil Holles Eamus. Deshil Holles Eamus. Deshil Holles Eamus. Send us bright one, light one, Horhorn, quickening and wombfruit (alo repeated thrice) (Joyce 1986: 314). This casts the band of young men in the role of Ulysses' comrades on the Island of Trinacria, when they devoured in order to satisfy their hunger the sacred kine of the God Helios; the parallel explains the "oxen of the sun" title, especially as Mr Bloom is also present in the same maternity lobby, but in a compassionate way to parturient "women in their allhardest of hours." So, whereas the stampede into the maternity hospital of the young Oxen of the Son (by a quite plausible pun between "son" and "sun") is highly offensive to women in virtue of their leading role in procreation, the mature male's silence is more restrained, or prudent (which is why $\mathrm{Mr}$ Bloom is referred to as "the prudenter" in this episode). It is by contrast to the sin against procreation, then, that Stephen, "the bullock befriending bard" introduces the postcreation, as shown above. And he makes his point stronger in the following quotation from the same episode that announces what Stephen could do as a writer in nuce when parodying the styles of so many dead writers:

Glaucon, Alcibiade, Pisistratus. Where were they now? Neither knew. You have spoken of the past and its phantoms, Stephen said. Why think of them? If I call them into life across the waters of Lethe will not the poor ghosts troop to my call? Who supposes it? 
I, Bous Stephanoumenos, bullockbefriending bard, am lord and giver of their life. (Joyce 1986: 339)

What Stephen adds in "Oxen of the Sun" to the savvily remembered details of the earlier Shakespearian biography and exhaustive critical bibliography advanced in "Scylla and Charibdis" is, as in the Credo, the declarative faith in (his own) fabrication: and the result is the incredible parodic monument to subliminally remembered styles of canonical English prose in "Oxen of the Sun." Earlier, Stephen seemed ready to dismiss his own fabrication of Shakespeareana, inviting anyone to disbelieve his theory about the bard's marital life and parental preferences, but in "Oxen of the Sun" Stephen seems to abide by his own theory of the postcreation, giving it more and more substance in the body of the episode in question. Because Stephen demonstrates his amazing stylistic competence, the prowess, and solidity of his literary knowledge, "Oxen of the Sun" can be regarded as the mise en abime episode of Ulysses as a whole. With the demonstration about the way an Irish colonized mind can contain and disdain the peaking styles of the colonizer's canonical, cultural memory texts, the author of the "Oxen of the Sun" has, demonstrably, started to grapple with what, at the end of A Portrait of the Artist - as a mere - Young Man, had been just wishful thinking: "to forge, in the smithy of [his] soul the uncreated conscience of his race" (Joyce 1992: 176).

The fact that this conscience reaches beyond the antagonistic cultural memory mode of nationalist, oppositional discourses can be shown by connecting Stephen's postcreation to the implied author's "final word" on fabrication in the last but two episode of the book, "Eumaeus." Here, "fabrication" is repeated in two almost perfectly equivalent contexts. At its first occurrence, it is "complete fabrication":

Taking Stephen on one side he [Lord John Corley] had the custormay doleful ditty to tell. Not as much as a farthing to purchase a night's lodgings. His friends had all deserted him. Furthermore he had a row with Lenehan and called him to Stephen a mean bloody swab with a sprinkling of a number of other uncalled for expressions. He was out of a job and implored Stephen to tell him where on God's earth he could get something, anything at all, to do. No, it was the daughter of the mother in the wash kitchen that was fostersister to the heir of the house or else they were connected through the mother in some way, both occurrences happening at the same time if the whole thing wasn't a complete fabrication from start to finish. Anyhow he was all in. (Joyce 1986: 504) 
It is to be noted that Lord John Corley is very much like Stephen (in exterior circumstances only: deserted by his friends, has nowhere to sleep, and is the eldest son of a police inspector and of a woman of reputedly nobler blood - as Stephen's - and James Joyce's - mother was). The character's fabrication - in both the subjective and objective genitive sense - is ridiculous as presented within the quoted passage, in Stephen's selectively omniscient narration. Lord John Corley's whole story may well be forged, to match, by a perfect parallelism, the story of his would-be lordly identity.

Seven hundred and three lines of prose further in Gabler's edition of Ulysses, fabrication appears in a passage where Mr Bloom and Stephen are listening to the story that the sailor D.B. Murphy is telling; in an aside addressed to Stephen, Mr Bloom comments about the "host of things and coincidences... possibly being]... not an entire fabrication... though... there was not much inherent probability... [of its] being strictly accurate gospel." Typically, Mr Bloom gets in a more roundabout way than Stephen to the core of the "entire fabrication," which is virtually similar to the earlier "complete fabrication":

"Our mutual friend's stories are like himself," Mr Bloom said apropos of knives remarked to his confidante sotto voce. Do you think they are genuine? He could spin those yarns for hours on end and lie like old boots. Look at him.

Yet still, though his eyes were thick with sleep and sea air life was full of a host of things and coincidences of a terrible nature and it was quite within the bounds of possibility that it was not an entire fabrication though at first blush there was not much inherent probability in all the spoof he got off his chest being accurate gospel. (Joyce 1986: 519)

This indicates perfect analogies between the fabrications (in the sense of forged tales) in the two passages and draws attention to the similarly correct identification of cheap fabrications for what they are in Mr Bloom's and Stephen's complementary discourses. We are also made sensitive to further insistent parallelisms that structure the text. Given that, in the ironic frame of this humble style episode, one expects noble epic heroes to wear humble masks, both Lord John Corley and D. B. Murphy are demonstrably masks, doubles, swineheard caricatures of Stephen and Mr Bloom. Consequently, the two protagonists' encounter is doubled by the individual encounters of both Stephen and Mr Bloom with their grotesque doubles. By the classical drama standards, it is interesting to see that the moment of comic relief in the encounter with the swineheard-doubles precedes the more pertinent, serious 
encounter of the two protagonists which reaches a climax in the Ithacan episode.

Parallelisms which call attention to differences also enrich locally fabricated significance. Whereas Lord John Corley "had a customary doleful ditty to tell," and the doleful part of the story, with "His friends had all deserted him," apart from Mr Bloom, his older, newly acquired friend retrieving Stephen to Ithaca, potentially Stephen's own Ithaca (if Stephen were completely analogous to Telemachus) - D. B. Murphy's fabrications are not at all mournful. Rather, D.B. Murphy's story, when mathematically understood in its "primitives" (i.e. along essential lines), recalls the anecdotal details of Mr Bloom's overall life-story: a fabling story-teller who is also rambling from home has a faithless wife; she, of course, fails to measure up to the heroic prototypes and does not wait for her far-away husband to return; he and she also have an as good as fictitious son in their home - as revealed in the course of D. B. Murphy's fabrication, which there is no room to quote here. There is a deeper parallelism invited by the association of the four term analogy created along the lines of the two minor characters' fabricated stories and their status as caricatured doubles of the book's main characters. The lines of the thick-set caricatures lead to what fabrications have at their heart, in hiding: young men's stories are mournful ditties, and prove their inclination to adopt the tragic stance when confronted with life's, and love's, bitter mystery. Older, experienced men's stories, like Mr Bloom's and his comic double, D.B. Murphy, need to fake detachment in the face of life's imponderables: ill luck as a cause for failing to control things better and failing to be glamorous enough - for their wives, say.

But the close text analysis of the fabrication fragments also points further. The larger space given to D. B. Murphy's than to Lord John Corley's story in the Cabman's Shelter discourse, in "Eumaeus," is analogous to the longer role accorded in Ulysses to Mr Bloom's controlling story; it becomes, therefore, the story of a modern adult everyman - who will befriend and bring (to his) home (the story of) a very uncommon young man. Length also strengthens the status of this fabrication and allows regarding it as a more complex intertextual practice with a relevant message to convey. Defined as "the spinning of yarns," it recalls, to a twentieth century reader, first Joseph Conrad's Marlow, the unusual seaman who spins very meaningful and humane yarns that go to the heart of things. In Heart of Darkness, Marlow's business had been to puncture highfalutin social fabrications, like D. B. Murphy's who "had a customary seaman's story to tell," or like the selfdeceiving tall tale of Kurtz's Intended while she is convincing both herself and Marlow at the end of the novella about the need of granting to Kurtz 
the status of a Western colonial god. In the same connection, the opening of the passage with the words "Our mutual friend," if capitalized, point(s) to the same commonplace, nondescript and collectively contemptible protagonist of Dickens's satire of anonymity in Our Mutual Friend.

In Ulysses, however, the ironic targets are more diverse and sophisticated. They represent clues about the composition of the book which moves between two extremes: it both uses and abuses gratuitous literary fabrication and sophisticated cultural parallelisms; it turns, on the one hand, mere fabrication into postcreation, and, on the other hand, mechanically understood intertextual parallelisms into parallactic collocations. One gains access to the meanings of the strong members of the pairs, parallax as against parallel, and postcreation as against fabrication, indirectly: from behind the more predictable, or perhaps commonplace, pair terms. With the foursome of Ulyssean keywords, the account about the Joyce contra Jung confrontation comes full circle, but it also points to the existence in Ulysses of an upper tier of literary interpretation (and composition), superior to that of the literal and figural ones. The Joycean book written after the youthful Bildungsroman, A Portrait of the Artist as a Young Man, still bears traces of the mediaeval fourfold meanings that pursue the Jesuit, in allowing one to glimpse a tropological, or ironically anagogical level of textual interpretation.

The constellation of modern parallelisms with the Odyssey is obtained, however, with a parallactic drift. By analogy with the imperfect caricatures in respect to the protagonists in "Eumaeus," it is possible to interpret the approximate, drifting analogies with the Odyssey that give meaning to the whole. Such drifting analogies measure the distance of the modern from the ancient world-order. It is ironic, indeed, as Jung noticed (without relishing the - possibly bitter - irony!), that a novel(istic) Odyssey should be centred on a character lacking in heroic deeds - and a cuckold, too, for that matter; or that the Penelope of Joyce's book should come to the fore as an adulteress yielding to available suitors; or that, again, the father and son relationship should be fabricated circumstantially in psychoanalysable, cultural and emotional terms rather than being a substantial kinship relation. If understood as being Stephen's, the artistic achievement on which Joyce's maturer art resides in Ulysses implements the young man's artistic ban on kinetic art $^{2}$.

The full quotation from A Portrait of the Artist as a Young Man, Chapter V, is "the tragic emotion is static. Or rather the dramatic emotion is. The feelings excited by improper art are kinetic, desire or loathing (Joyce 1992: 222). 
There is, recognizably, in this ban, a valedictory plea: that of modernist art "forbidding mourning" (breaking with traditional writing recipes in radical ways). What one should also accept, however, is that Ulysses anticipates postcolonial art's forbidding the endless bickering between the colonizer and colonized discourses vying with each other in literary documents. It is, also, maybe, less easy to accept that Joyce's is a kind of art that foregrounds even poststructuralist/postmodern cultural directions. And yet this is, demonstrably, the case, if Joyce's Ulysses can be subsumed to the point made by Slavoj Žižek's 2006 The Parallax View.

A detour is required here before closing the demonstration with this last argument. The foursome of fabrication, parallel, parallax, and postcreation as the sustainable core of the book's last three episodes makes the traditional healing function of irony which restores commonsense and corrects excesses be both established and exceeded. The foursome mentioned warrants that no leading character's perceiving consciousness can legitimately be seen as merely passive. Fabrication, parallel parallax and the modernist faith in postcreation fluidize the narrative and confer to the Nostos the quality of an elegant demonstration about the meaningful freedom ideally granted to individuals - by ironically handled, and evenly balanced, fictional and cultural associations. The initial quotations from "Lestrygonians" and the final ones, from "Ithaca," chart the path from the use of parallax as a figure for the advancement of Mr Bloom's individual positive intuition and momentary fabrications towards publicly acceptable positive knowledge derived from astronomical facts.

The progress from the self-reflexive intra-mediating powers of parallelism as a rhetorical device to the rhetorical powers of the parallax can be more clearly understood with Žižek's book and its use of Lacanian deconstructive indecidables; they form the basis for establishing a juster, less alienating social link. "[T]he parallax function at its purest," Žižek writes is the palpable expression of the fact that "the gap between the two versions is irreducible, it is the 'truth' of both of them, the traumatic core around which they circulate; there is no way to resolve the tension, to find a 'proper' solution" (Žižek 2006: 19). We are definitely on unstable irony territory, according to Wayne Booth's study of irony in his book's last chapter. Yet, rather than being besieged by infinite irony with its honest dramatization of meaninglessness, when reading Ulysses parallactically, one feels reconciled by the meanings which connect the protagonists at the end. Ultimately, the father and son reunion is only emotional and momentary, though, being, as shown at the beginning, infinitely expansive: communing as wide as to cover the whole range of human and cosmic life on the spur 
of the momentous pronouncement under "the heaventree of stars hung with humid nightblue fruit," right before the meditations that accompanied $\mathrm{Mr}$ Bloom's "demonstration to his companion [Stephen] of various constellations" and "of the parallax or parallactic drift of socalled fixed stars, in reality evermoving wanderers" (Joyce 1986: 573).

The following words written by Žižek so much later than the text of Ulysses appear to hit the Joycean target:

The standard definition of parallax is: the apparent displacement of an object (the shift of its position against a background), caused by a change in observational position that provides a new line of sight. The philosophical twist to be added, of course, is that the observed difference is not simply "subjective," due to the fact that the same object which exists "out there" is seen from two different stances, or points of view. It is rather that, as Hegel would have put it, subject and object are inherently "mediated," so that an "epistemological" shift in the subject's point of view always reflects an "ontological" shift in the object itself. (Žižek 2006: 6)

Joyce approximated this ontological shift by accommodating cultural memory ironically in his game (or gaze?) of postcreation that articulated, through fabrications reprocessed as parallelisms, the parallactic drift towards truth of only momentarily, or very partial, coinciding points of view in movement.

\section{References}

Booth, W. (1974). A Rhetoric of Irony. London and Boston: The University of Chicago Press.

Errl, A. (2008). Literature, Film and the Mediality of Cultural Memory. In A. Erll, A. Nunning and S. Young (Eds.), Cultural Memory Studies. Berlin-New York: De Gruyter, 389-398.

Gifford, D. and R. Seidman. (1989) Ulysses Annotated: Notes for James Joyce's Ulysses, Berkley-Los Angeles-London: University of California Press.

Joyce, J. (2012). Ulysses. S. Slote (Ed.) Richmond: Alma Classics. Print.

Joyce, J. (1986). Ulysses. H. W. Gabler, W. Steppe and C. Melchior (Eds.) New York: Vintage Books.

Joyce, J. (1992). A Portrait of the Artist as a Young Man.Seamus Deane (Ed). London: Penguin.

Joyce, J. (1975). To Carlo Linati (21 Sept. 1920). In R. Ellmann (Ed.) Selected Letters. New York: Viking, 270-71. 
Jung, C. G. (2003). The Spirit in Man, Art and Literature. London-New York: Routledge.

Rigney, A. (2004). Portable Monuments: Literature, Cultural Memory, and the Case of Jeanie Deans. Poetics Today 25(2), 361-396).

Žižek, S. (2006). The Parallax View. Cambridge, Massachusetts-London, England: Massachusetts Institute of Technology. 